\title{
SOUTH AMERICAN GIANT SHORT-FACED BEAR (ARCTOTHERIUM ANGUSTIDENS) DIET: EVIDENCE FROM PATHOLOGY, MORPHOLOGY, STABLE ISOTOPES, AND BIOMECHANICS.
}

LEOPOLDO H. SOIBELZON, ${ }^{1}$ GUSTAVO A. GRINSPAN, ${ }^{2}$ HERVÉ BOCHERENS, ${ }^{3}$ WALTER G. ACOSTA, ${ }^{4}$ WASHINGTON JONES, ${ }^{2}$ ERNESTO R. BLANCO,${ }^{5}$ AND FRANCISCO PREVOSTI ${ }^{6}$

${ }^{1}$ Departamento Científico Paleontología de Vertebrados, Museo de La Plata, Paseo del Bosque, La Plata B1900FWA, Argentina. <1soibelzon@fcnym. unlp.edu.ar>; ${ }^{2}$ Núcleo de Biomecánica, Espacio Interdisciplinario, Universidad de la República, Rodó 1843, Montevideo 11200, Uruguay; ${ }^{3}$ Department of Geosciences, Biogeology, University Tübingen, Hölderlinstrasse 12, 72074 Tübingen, Germany; ${ }^{4}$ Cátedra de Semiología, facultad de ciencias Veterinarias Universidad Nacional de La Plata. La Plata, Argentina; ${ }^{5}$ Instituto de Física, Facultad de Ciencias, Universidad de la República, Igua 4225, Montevideo 11400, Uruguay; and 'División Mastozoología, Museo Argentino de Ciencias Naturales "Bernardino Rivadavia"-CONICET, Av. Angel Gallardo 470, C1405DJR, Buenos Aires, Argentina

\begin{abstract}
Arctotherium angustidens Gervais and Ameghino, 1880 (the South American giant short-faced bear) is known for being the earliest (Ensenadan Age, early to middle Pleistocene) and largest (body mass over 1 ton) of five described Arctotherium species endemic to South America. Here we assess the diet of this bear from multiple proxies: morphology, biomechanics, dental pathology, stable isotopes and a previous study using geometric morphometric methodology. Results favor the idea of animal matter consumption, probably from large vertebrates in addition to vegetable matter consumption. Most probably, active hunting was not the unique strategy of this bear for feeding, since its large size and great power may have allowed him to fight for the prey hunted by other Pleistocene carnivores. However, scavenging over mega mammal carcasses was probably another frequent way of feeding. South American short-faced bears adjusted their size and modified their diet through Pleistocene times, probably as a response to the diversification of the carnivore guild (from the few precursory taxa that crossed the Panamanian Isthmus during the Great American Biotic Interchange).
\end{abstract}

\section{INTRODUCTION}

$\mathrm{S}$ OUTH AMERICAN short-faced bears (Ursidae,Tremarctinae) were represented by one genus (Arctotherium Burmeister 1879) and five species: A. angustidens Gervais and Ameghino 1880; A. wingei Ameghino 1902; A. vetustum Ameghino 1885; A. bonariense (Gervais 1848-1852) and A. tarijense Ameghino 1902 (Soibelzon, 2004). Of these, A. angustidens (the giant short-faced bear, hereafter "giant SFB") is the only species recorded in the early to middle Pleistocene (Ensenadan) of Argentina and in Pleistocene (?) sediments of Bolivia (Soibelzon et al., 2005), the other four species are recorded from the middle Pleistocene to the latest Pleistocene (Bonaerian and Lujanian) in Chile, Bolivia, Uruguay, Venezuela, Brazil, and Argentina (Soibelzon et al., 2005; Soibelzon and Rincón, 2007; Rodrigues et al., 2012). The only living representative of the Tremarctinae subfamily is the spectacled or Andean bear, Tremarctos ornatus (Cuvier, 1825).

Short-faced bears arrived in South America from North America through the Panamanian Isthmus during the Great American Biotic Interchange (Marshall et al., 1982) like all eutherian carnivores (Soibelzon and Prevosti, 2007, 2012; Prevosti and Soibelzon, 2012). By the early Pleistocene, there were only two very large mammalian predators (i.e., body mass over $200 \mathrm{~kg}$ ) in South American ecosystems: the giant SFB, a gigantic carnivore-omnivore (body mass as high as 1,588 and $1,749 \mathrm{~kg}$, see Soibelzon and Schubert, 2011), and the Sabretooth cat Smilodon populator Lund, 1842, a constrained hypercarnivore (Soibelzon et al., 2009). In addition, two records of Homotheriini (cf. Xenosmilus Martin et al., 2000 in Uruguay; Mones and Rinderknecht, 2004; and Homotherium venezuelensis Rincón et al., 2011 in Venezuela), as well as one record of Smilodon gracilis Cope 1880 also for Venezuela (Rincón et al., 2011), were reported, together with thousands of herbivore species with sizes ranging from that of a rodent to a five-ton ground sloth (Xenarthra, Mylodontidae) (see an updated list in Cione et al., 2009).

Our objective is to use evidence from anatomy, dental paleopathology, biomechanics, and stable isotopes to assess the diet of the giant SFB in order to understand its role in these particular and changing ecosystems. Molar morphology in bears, as in other omnivore carnivores (e.g., procyonids), is very constant inside clades showing only small differences between species that sometimes are enough for constructing taxonomy, but do not provide evidence of dietary particularities (Soibelzon, 2012). In this sense Sacco and Van Valkenburgh (2004) suggested that bear dental morphology may be less tightly constrained by ecological requirements than that of other carnivorans.

Information about diet may be discerned by the relative frequency of dental lesions, such as caries, periodontitis, periapical lesions ("abscesses"), fractures, attrition (extreme wear of the oclussal surface), etc. (Ferigolo, 1992). In turn, biomechanics provides bite force estimations from "dry skull" methods (Thomason, 1991; Wroe et al., 2005; Christiansen, 2007; Blanco et al., 2011). Leaving aside the body size effect on bite force, it is possible to estimate a bite force quotient (BFQ, a relation between actual bite force and expected bite force by body size), which correlates with prey size as was shown in Christiansen and Wroe (2007). Therefore, estimations of this index are very informative of the paleobiology of a mammalian predator. Another approach to the study of bite mechanics is to model the mandible as a cantilever beam in order to estimate the loads when biting in different positions along the tooth row, thus obtaining a mandibular force profile (MFP, Therrien, 2005a). In order to reduce the size differences, the MFP results are transformed to logarithmic values. Both methods have been 
applied to several species of living ursids and other species of extant mammals (Therrien, 2005a, 2005b; Christiansen, 2007) and have proven to be very powerful tools in order to realize paleobiological inferences about feeding behavior. These have also been used to study some extinct species such as Canis dirus Leidy 1858 and Panthera atrox Leidy 1858 (Therrien, 2005a), several Sabre-tooth mammals including the specialized borhyaenoid Thylacosmilus atrox Riggs 1933 (Therrien, 2005b), and three representative species of borhyaenoids as Cladosictis patagonica Ameghino 1887, Prothylacinus patagonicus Ameghino 1891, and Borhyaena tuberata Ameghino 1887 (Blanco et al., 2011).

Stable isotopic tracers in fossil bones and teeth of Pleistocene and other Cenozoic age organisms have been used to reconstruct paleodiets and trophic relationships (e.g., Bocherens et al., 1995a, 1995b, 1996). This approach is based on the fact that carbon (in collagen and the carbonate fraction of bioapatite) and nitrogen (in collagen) exhibit isotopic signatures linked to those of the diet consumed by an animal during the formation of the analyzed tissues. When collagen is not preserved, which is usually the case in early Pleistocene skeletal fragments, using the carbonate fraction of enamel bioapatite as a support for biogenic carbon isotopic signatures is a powerful approach to yield valuable information about habitat and diet (e.g., Bocherens et al., 1994, 1995a, 1996, 2011; Clementz et al., 2009; Garcia Garcia et al., 2009; Pushkina et al., 2010; Ecker et al., 2013). Carnivores exhibit a specific isotopic fractionation of carbon between their skeletal carbonate and that of their prey (Bocherens, 2000; Clementz et al., 2009). In the case of bears, carbon and nitrogen isotopic investigations of fossil bone collagen have shown that coexisting brown bears (Ursus arctos) and cave bears (Ursus spelaeus) exhibited different dietary preferences, with a clearly herbivorous diet for cave bears while Pleistocene brown bears consumed a lot of meat (e.g., Bocherens et al., 2011). Carbon isotopic studies of Pleistocene brown bear and cave bear tooth enamel have shown that this dietary difference is also reflected in the carbon isotopic composition of these bears, with cave bears exhibiting lower ${ }^{13} \mathrm{C}$ values than brown bear and predatory carnivores (e.g., Garcia Garcia et al., 2009; Feranec et al., 2010; Ecker et al., 2013). In order to use this approach at other paleontological sites, such as the South American Pleistocene ones, a better way to quantify this parameter is to express this difference by comparison with coeval ungulates, representing the possible prey of the predators. Using published isotopic data from European late and middle Pleistocene sites (Bocherens et al., 1995b; Garcia Garcia et al., 2009; Feranec et al., 2010; Ecker, 2011), a clear difference is visible between the pattern of brown bears (carnivorous omnivores) and cave bears (herbivorous omnivores) (Fig. 1): cave bears exhibit the smallest difference, while brown bears show a difference intermediate between that of cave bears and that of predatory carnivores, such as cave hyenas and wolves. In the present study, a similar approach is used for Arctotherium fossil teeth compared to those of coeval herbivores, and the difference between the carbon isotopic composition of the fossil bears and herbivores are compared with that of European Pleistocene bears to evaluate the degree of carnivory.

A microwear analysis is not applicable to South American SFB, because in species with potentially omnivore diet the interpretation of hard plant versus bone consuming signatures is problematic (Blaine Schubert, personal commun. to LHS, 2010).
MATERIAL AND METHODS

Specimens of $A$. angustidens studied here are listed and described in Soibelzon (2004, 2012), Soibelzon et al. (2005) and Soibelzon and Schubert (2011). Measurements used to calculate the ratio skull length/P4-M2 length (ratio SL/P4M2) and skull length/M1 width (SL/M1W) of Arctotherium angustidens and Arctodus simus were taken from Soibelzon (2012); those of Ursus spelaeus from Torres (1988) and those of Ailuropoda melanoleuca from specimens deposited at National Museum of Natural History (Smithsonian Institution, U.S.A.).

Chronostratigraphic/geochronologic units (Ensenadan, Bonaerian, and Lujanian) are those of Woodburne et al. (2006). Measurements were taken with dial calipers.

Pathology.-Ferigolo and Berman (1993) briefly reported some of the pathologies observed in South American SFB. Dental pathologies and tooth damage observed in South American SFB were grouped into three main categories or types by Soibelzon (2012). Type I are those derived from the extreme wear or attrition of the crown surface, type II are those caused by chewing on hard objects. Teeth were counted as broken only if they showed evidence of subsequent wear in life in the form of distinct wear facets formed by tooth-tooth or tooth-food contact (Van Valkenburgh, 1988; Van Valkenburgh and Hertel, 1993). Finally type III are caries, linked with low $\mathrm{pH}$ environment in the oral cavity possibly, but not only, caused by the ingestion of food rich in carbohydrates like fruits.

Biomechanics.-Bite forces (BFs) were estimated using a static model involving reconstructions of physical cross-sectional areas of the main jaw adductor muscles (temporalis and masseter) and their respective in levers about the temporomandibular joint (Thomason, 1991; Wroe et al., 2005; Blanco et al., 2011), together with the linear distances from the temporomandibular joint to the center of the upper canine. The latter constitute outlever moment arms of the model. Measurements were taken from pictures of three specimens of $A$. angustidens: MLP 82-X22-1, MACN 12529, and MACN 48 (see Table 1). Some data was computed from the images such as: overall skull length (premaxilla to the occipital condyles), the cross-sectional areas of the major jaw adductors and their respective inlever moment arms about the temporomandibular joint, together with outlever moment arm for the jaw adductors about the temporomandibular joint (Fig. 2). The jaw adductor cross-sectional areas were measured using the image processing software Image J $1.40 \mathrm{~g}$ (free online version for Windows). That area was multiplied by the estimated maximal isometric force generated by mammalian muscle $\left(30 \mathrm{~N} / \mathrm{cm}^{2}\right.$, Close, 1972) to estimate each muscular force.

As indicated in Thomason (1991), it was assumed that the resultant force vectors of the jaw adductors about the temporomandibular joint ( $\mathrm{T}$ for the temporalis and $\mathrm{M}$ for the masseter, respectively) acted through their respective centroids perpendicular to the plane of the muscle cross-sectional area. Bite force can be estimated as:

$$
\mathrm{BF}=\left(T . I_{t}+M . I_{m}\right) / I_{o}
$$

where $M$ and $T$ are the estimated maximal isometric forces of masseter and temporalis respectively, and $I_{m}$ and $I_{t}$ are their respective inlevers about the temporomandibular joint. $I_{o}$ is the outlever moment arm from the center of the temporomandibular joint to the center of the upper canine, upper fourth premolar, and upper second molar (Wroe et al., 2005; Christiansen, 2007; Blanco et al., 2011). All measurements are in SI units, and the bite force value is in Newtons $(\mathrm{N})$. The body mass estimations were taken from Soibelzon and Tartarini (2009) and are listed in Table 1. An estimated Bite Force Quotient (BFQ) was calculated to compare bite force values in extant bear species with differences in body mass. BFQ on the upper canines and upper 


\section{Ursus spelaeus \\ Ursus arctos \\ carnivores \\ Arctotherium}

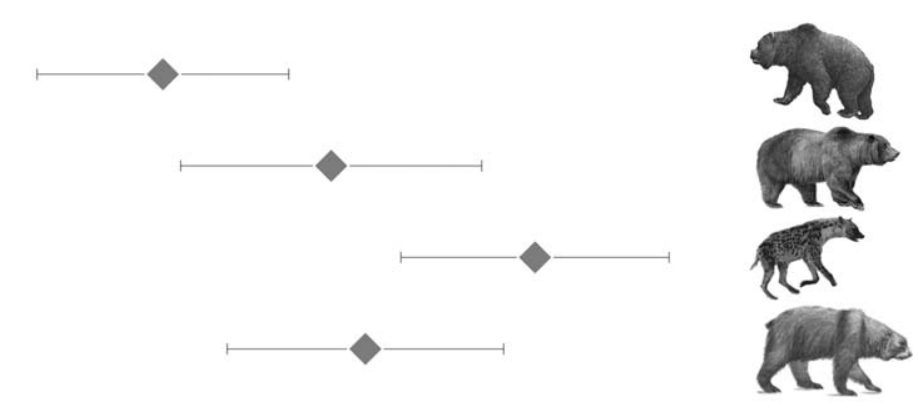

$\begin{array}{ccccccc}-6 & -5 & -4 & -3 & -2 & -1 & 0 \\ & \Delta \delta^{13} C_{\text {carn-herb }}\end{array}$

Figure 1 -Difference between the $\delta^{13} \mathrm{C}$ values of Arctotherium and coeval herbivores in Toscas del Rio de la Plata site, as well as predatory carnivores, brown bears Ursus arctos and cave bears Ursus spelaeus in European Pleistocene sites (see text for details). The $\mathrm{X}$-axis represents $\mathrm{D} \delta^{13} \mathrm{C}_{\text {carn-herb }}$, which is the difference of average $\delta^{13} \mathrm{C}$ values between the carnivores (including bears) and the $\delta^{13} \mathrm{C}$ values of herbivores in the same site. Such a value for Arctotherium is similar to that of the omnivorous/carnivorous brown bear and clearly higher than that of herbivorous cave bear, indicating a significant contribution of meat in its diet.

fourth premolar was calculated using the following equations present in Christiansen and Wroe (2007):

$$
\mathrm{BFQ}_{\text {canine }}=\left[\mathrm{CBs} / 10^{(0.663 \pm 0.028 \times \log 10 \mathrm{BoM}+1.561 \pm 0.027}\right] \times 100
$$

$\mathrm{BFQ}_{\text {carnassial }}=\left[\mathrm{CaBs} / 10^{(0.650 \pm 0.028 \times \log 10 \mathrm{BoM}+1.762 \pm 0.028}\right] \times 100$

where $\mathrm{CBs}$ is the bite force at the canines, $\mathrm{CaBs}$ is the bite force at the upper fourth premolar and BoM is the body mass (expressed in $\mathrm{kg}$ ).

To obtain mandibular force profiles (MFP), we followed the methods outlined by Therrien (2005a). The resistance to bending of the lower jaw in the parasagittal and sagittal planes was approximated by measuring the external dorsoventral and labiolingual diameters of the lower jaw at five intervals along the jaw ramus: the interdental gaps between $\mathrm{m} 3 / \mathrm{m} 2, \mathrm{~m} 2 / \mathrm{m} 1, \mathrm{~m} 1 /$ $\mathrm{p} 4, \mathrm{p} 4 / \mathrm{p} 3$ and at the jaw symphysis just posterior to $\mathrm{C} 1$, together with their respective linear distances from the center of the lower jaw condyle (Fig. 3). As outlined by Therrien (2005a), the dorsoventral measurement at the mandibular symphysis was taken just posterior to the canine, and the labiolingual measurement was taken at an angle to the long axis of the jaw ramus (see Fig. 3). The second moment of area about the dorsoventral $\left(I_{X}\right)$ and labiolingual $\left(I_{Y}\right)$ planes in bending is computed as:

$$
\begin{aligned}
& I_{X}=\left(B \cdot y \cdot x^{3}\right) / 64 \\
& I_{Y}=\left(B \cdot y^{3} \cdot x\right) / 64
\end{aligned}
$$

where $\mathrm{x}$ and $\mathrm{y}$ are the dorsoventral and the labiolingual external diameters of the jaw ramus respectively. All length measurements are in centimeters, as used in previous works (Therrien, 2005a, b; Christiansen, 2007). The section moduli for bending in the above planes $\left(Z_{x}, Z_{y}\right)$ are:

$$
\begin{aligned}
& Z_{x}=I_{X} /(x / 2) \\
& Z_{y}=I_{Y} /(y / 2)
\end{aligned}
$$

The bending moment $(\mathrm{M})$ is the force $(\mathrm{F})$ multiplied by the perpendicular distance (L) of the particular section modulus in question to the mandibular condyle $(M=F . L)$. Thus, the maximal applied force at any given point along the jaw should be proportional to the ratio of the section modulus to the distance from the jaw condyle $(Z / L)$. This measure is useful to compare adaptive differences between species with various feeding techniques (Therrien, 2005a, 2005b; Christiansen, 2007). A higher ratio implies the capability to resist greater forces. The comparison is possible if it is assumed that the safety factors are broadly similar among the various species, which seems likely (see Alexander, 1981). However, our estimation of BFQ, described in this section, uses a completely different set of cranial measurements giving us additional evidence bearing on this point. Therefore, a comparison of $\mathrm{Z} / \mathrm{L}$ ratios for different taxa will reveal variations in the magnitude of applied force at different locations along the mandible, whereas the ratio $Z_{x} / Z_{y}$ will reflect the relative mandibular strength for bending in different planes. Results were log-transformed in order to reduce the effect of size differences. Comparison of these mandibular

\begin{tabular}{|c|c|c|c|}
\hline & \multicolumn{3}{|c|}{ Specimen } \\
\hline & MLP $82-X-22-1$ & MACN 12529 & MACN 48 \\
\hline Temporalis group moment arm $(\mathrm{cm})$ & 4.68 & 5.35 & 4.73 \\
\hline Masseter group moment arm $(\mathrm{cm})$ & 7.28 & 5.92 & 6.19 \\
\hline Cross-sectional area of masseter group $\left(\mathrm{cm}^{2}\right)$ & 90.42 & 57.43 & 87.51 \\
\hline Body mass $(\mathrm{kg})$ (Soibelzon and Tartarini, 2009) & 700 & 663 & 667 \\
\hline Outlever moment arm $(\mathrm{cm})$ - teeth location: upper canine/P4/M2 & 28.5/19.78/13.52 & $27.3 / 21.17 / 14.58$ & $27.4 / 21.08 / 15.66$ \\
\hline
\end{tabular}
biomechanical properties between various predatory mammals has the potential to reveal similarities and differences in their feeding behavior (Therrien, 2005a, 2005b). This method was

TABLE 1 - Input data for biomechanical analysis. 

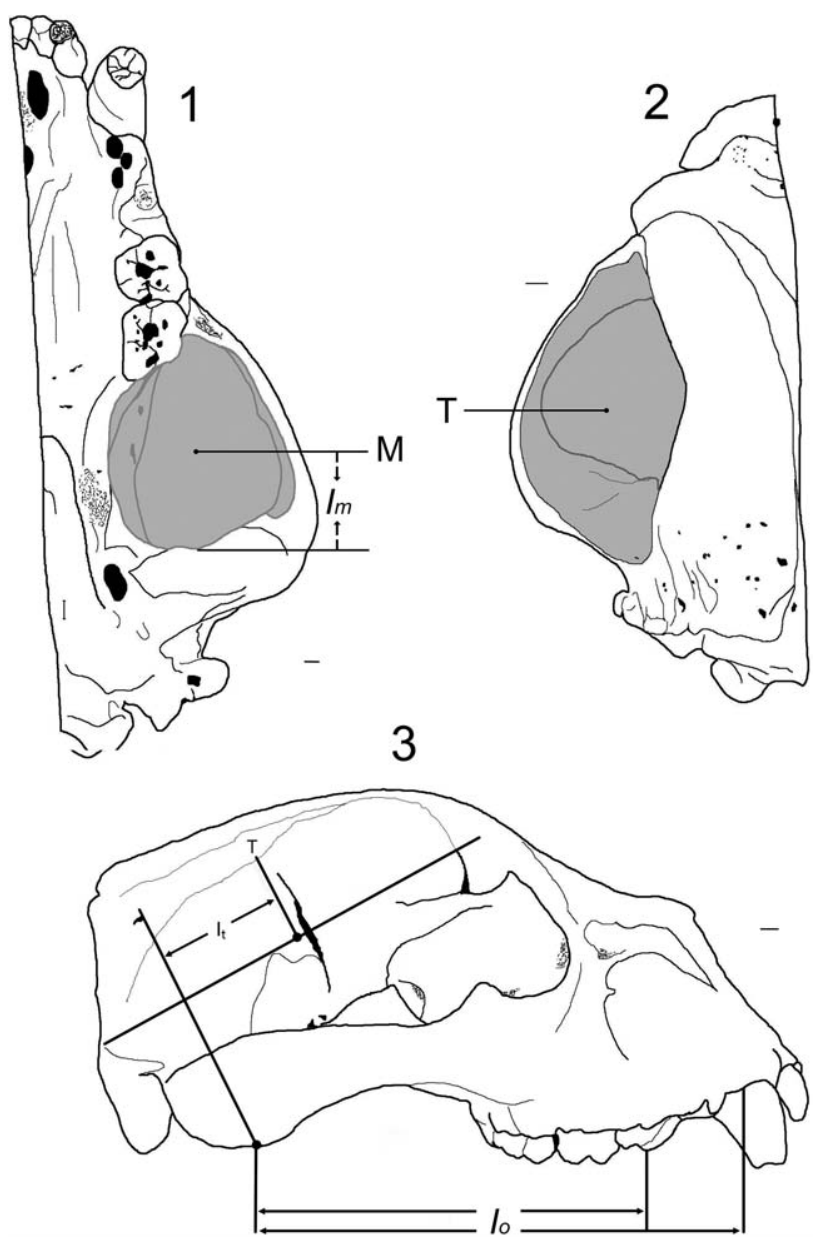

FIGURE 2-Skull of Arctotherium angustidens MLP 82-X-22-1 indicating the approximate cross-sectional areas (shaded) of the masseter-pterygoid and temporalis muscles, and the other measurements used in the dry skull analysis. 1 , palatal view, showing the resultant force vector of the masseter-pterygoid (M), acting through the centroid (black circle) and the inlever moment arm for the masseter-pterygoid about the temporomandibular joint $(\operatorname{Im}) ; 2$, posterodorsal view, showing the resultant force vector of the temporalis (T), acting through the centroid; 3, lateral view, showing the inferred inlever moment arm of the temporalis about temporal joint (It), and outlever moment arm from temporal joint to the center of the upper canine and upper fourth premolar (Io). Scale bars $=1 \mathrm{~cm}$.

applied to the BMNH 32916 and MMPH 018 specimens of A. angustidens. All data used for MFP are in Table 2.

Morphology.- In discussing dental morphology and systematics, we rely greatly on the nomenclature and characters used by Soibelzon (2004); we follow Smith and Dodson's (2003) terminology for anatomical notation and orientation of dentition.

Isotopic analysis.-Tooth material from an early Pleistocene site, Toscas del Rio de la Plata, including SFB (Arctotherium angustidens), equids (Hippidion Owen 1869), camelids (Hemiauchenia Gervais and Ameghino 1880), and notungulata (Mesotherium cristatum Serrés 1867) was handled to separate about $10 \mathrm{mg}$ of pure enamel powder and thereafter treated to remove any possible carbonate contaminant using an acetic acid pretreatment (Bocherens et al., 1996). So far only material from this site, containing SFB together with other mammal taxa, was made available for an isotopic study.

The $\delta^{13} \mathrm{C}$ measurements of the carbonate fraction of tooth enamel were performed at the Department of Geosciences (University Tübingen, Germany). Prior to these analyses of the bone mineral fraction, bone powders were chemically pre-treated
1
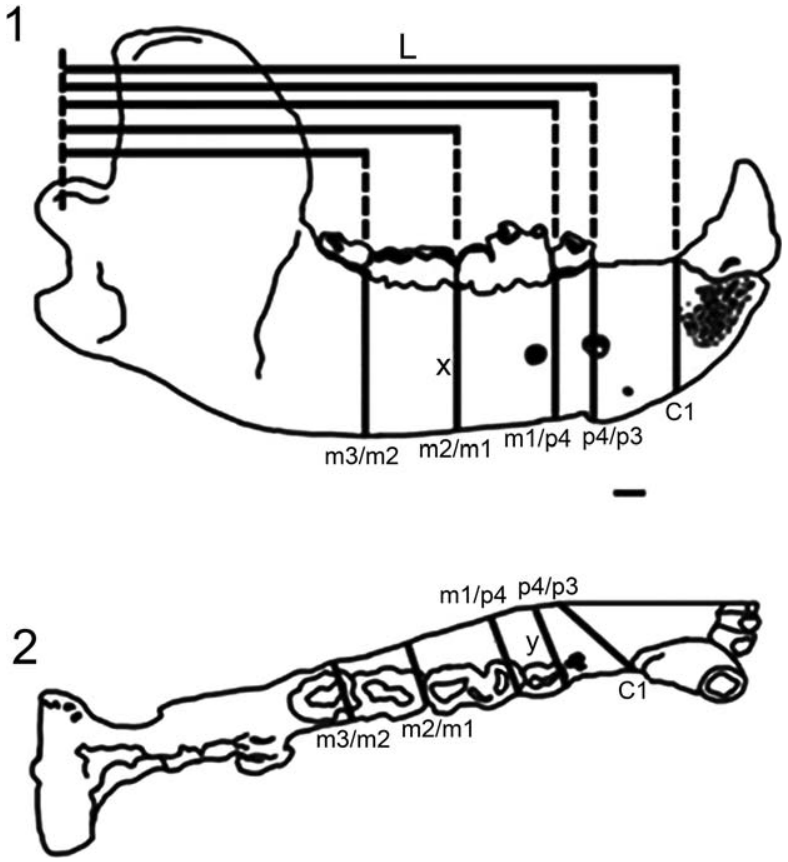

FIGURE 3-Mandible of Arctotherium angustidens MMPH 018 indicating the measurements used in the mandibular force profile method. 1, lateral view, indicating the dorsoventral diameters of the jaw ramus (x) at five intervals $(\mathrm{m} 3-\mathrm{m} 2, \mathrm{~m} 2-\mathrm{m} 1, \mathrm{ml}-\mathrm{p} 4, \mathrm{p} 4-\mathrm{p} 3$ and canine at jaw symphysis) and the corresponding linear distances from the center of the jaw condyle (L); 2, dorsal view, showing the measured labiolingual diameters (y) at the same five intervals. Scale bar $=1 \mathrm{~cm}$.

with 2 percent $\mathrm{NaOCl}$ solution, followed by a $0.1 \mathrm{M} \mathrm{Ca}$-acetate acetic acid buffer solution (Bocherens et al., 1996). Samples were analysed at $70^{\circ} \mathrm{C}$ using a ThermoFinnigan Gasbench II on a Finnigan Delta Plus XL CFIRMS at the University of Tübingen for $\delta^{13} \mathrm{C}$ values of the carbonate fraction of bioapatite. Carbon isotopic abundances are expressed as (delta) values in parts per mil (\%), as follows: $\delta^{13} \mathrm{C}=\left({ }^{13} \mathrm{C} /{ }^{12} \mathrm{C}\right.$ sample $/{ }^{13} \mathrm{C} /{ }^{12} \mathrm{C}$ standard -1$) \times$ 1000 . These delta values are reported relative to the international reference standard Vienna Pee Dee Belemnite (V-PDB). Analytical error was estimated to be $0.1 \%$ for $\delta^{13} \mathrm{C}$ values based on replicate within-run analyses of lab standards.

The following abbreviations are used in the text: MACN, Museo Argentino de Ciencias Naturales "Bernardino Rivadavia"; MLP, Museo de La Plata, Argentina; c, lower canine; C, upper canine; M1, first upper molar; M2, second upper molar; $\mathrm{m} 1$, first lower molar; $\mathrm{m} 2$, second lower molar; $\mathrm{m} 3$, third lower molar; $\mathrm{p} 3$, third lower molar, p4, fourth lower molar, P4, fourth upper molar.

\section{RESULTS}

Paleophatologies.-The most common pathologies observed on Arctotherium teeth are those related with the extreme wear of the oclussal surface (type I) of the incisors, canines and molar crowns (see Fig. 4.1) that, in some cases, caused the exposure of the pulp cavity (e.g., MHN 32915/6, MACN 5132, MACN 43, MACN 1443, MLP 10-4, MLP 99-X-3-1, MLP 87-V-5-1, MLP 00-VII-1-1, MMMP 1441, MMMP 26s; see left M1 and M2 on Fig. 4.1). We observed some specimens in which the wear is more pronounced in one side of the jaw than in the other. This is interpreted as a side preference for chewing.

The second most common pathologies are those caused by chewing on hard objects (type II), probably long bones, which produce tooth breakage or enamel chips and in some extreme cases a missing tooth (e.g., MLP 82-X-22-1, MACN 43, MMMP 3980, MMPH 18, MPS 60; see Fig. 4.2). Tooth breakage or 
TABLE 2-Parameters and values of the mandibular force profiles in the studied species. The values are presented in the following sequence, in agreement with the interdental gaps: $\mathrm{m} 3-\mathrm{m} 2, \mathrm{~m} 2-\mathrm{m} 1, \mathrm{~m} 1-\mathrm{p} 4, \mathrm{p} 4-\mathrm{p} 3$ and a point distal to canine.

\begin{tabular}{|c|c|c|c|c|c|c|c|c|}
\hline \multirow[b]{2}{*}{ Specimen } & \multicolumn{8}{|c|}{ Mandibular force profiles } \\
\hline & $\mathrm{L}(\mathrm{cm})$ & $\mathrm{x}(\mathrm{cm})$ & $\mathrm{y}(\mathrm{cm})$ & $\mathrm{Zx}\left(\mathrm{cm}^{3}\right)$ & $\mathrm{Zy}\left(\mathrm{cm}^{3}\right)$ & $\log (\mathrm{Zx} / \mathrm{L})$ & $\log (\mathrm{Zy} / \mathrm{L})$ & $\mathrm{Zx} / \mathrm{Zy}$ \\
\hline $\begin{array}{l}\mathrm{BMNH} \\
32916\end{array}$ & $\begin{array}{c}17.3,21.6,27 \\
29.3,33.7\end{array}$ & $\begin{array}{l}4.35,3.85,3.85 \\
\quad 3.65,3.35\end{array}$ & $\begin{array}{l}1.85,1.72,2.15, \\
2.72,4\end{array}$ & $\begin{array}{l}27.49,19.97 \\
25.03,28.4 \\
35.26\end{array}$ & $\begin{array}{l}11.69,8.89 \\
13.98,21.13 \\
42.1\end{array}$ & $\begin{array}{l}0.20,-0.03, \\
\quad-0.03,-0.01 \\
0.02\end{array}$ & $\begin{array}{l}-0.17,-0.39 \\
\quad-0.29,-0.14 \\
0.10\end{array}$ & $\begin{array}{c}2.35,2.24,1.79 \\
1.34,0.83\end{array}$ \\
\hline $\begin{array}{c}\text { MMPH } \\
018\end{array}$ & $\begin{array}{l}13.44,17.08 \\
19.88,22.96 \\
26.04\end{array}$ & $\begin{array}{l}3.64,3.22,3.22 \\
3.64,3.08\end{array}$ & $\begin{array}{l}1.48,1.66,1.85 \\
1.85,2.77\end{array}$ & $\begin{array}{l}15.35,13.52 \\
15.07,19.25 \\
20.6\end{array}$ & $\begin{array}{c}6.22,6.97,8.66 \\
9.78,18.49\end{array}$ & $\begin{array}{l}0.06,-0.10 \\
\quad-0.12,-0.08 \\
\quad-0.10\end{array}$ & $\begin{array}{l}-0.33,-0.39 \\
\quad-0.36,-0.37 \\
\quad-0.15\end{array}$ & $\begin{array}{c}2.46,1.94,1.74 \\
1.97,1.11\end{array}$ \\
\hline
\end{tabular}

chipped enamel is much more frequently observed on P4 and m2 than in other areas.

Skull MACN 12529 a large adult female (Soibelzon, 2012), exhibits significant dental pathologies. On the left side, the M1 shows that a big slab of enamel was lost in life; on M2 all the trigonid area was lost. On the right side, the P4 and M1-M2 shows excessive and abnormal wear probably produced by the enamel slab fractures on several sides of these teeth (lingual side of P4, mesial, distal, and lingual sides of M1, and lingual side of M2 talonid, see Fig. 4.3); this could interpreted as an individual preference to chewing on the right side because a big caries (involving pulp tissue) developed on the left P4. Finally, the incisive also shows several enamel chipped portions.

The adult female MMMP 3980 (described in Soibelzon et al., 2009) also shows broken teeth. In this case, the trigonid of the left $\mathrm{m} 2$ crown was lost in vivo conserving only the talonid (Fig. 4.4). The fracture occurred at the trigonid-talonid boundary leaving a flat inclined plane of dentine transverse to the mesio-distal axis of the tooth. It could be observed posttraumatic attrition over the enamel and dentine at the fracture border. Also, the exposition of the pulp cavity provoked a periapical infection evidenced by the irregular root and alveolar surfaces and increased alveolar space.

The skull MLP-82-X-22-1 corresponds to a large adult female that died relatively young. This individual shows several traumatisms on its teeth including a fragment of a consumed bone incrusted close to the mesial root of right P4 (Fig. 4.2). Left P4 was lost in life, producing a huge local infection and consequently a retraction of the alveolar bone and an oral-nasal fistula concerning only this alveolus (Fig. 4.5). This infection was active at the moment that MLP-82-X-22-1 died since it could be observed osteolityc and osteogenyc patters (without demodulation signs), implying an acute process. It could be presumed that this infection produced a mucopurulent unilateral nasal discharge. On the right side the $\mathrm{P} 4$ crown is transversally broken affecting the mesial half of the paracone and its root (Fig. 4.2). This fracture shows acute wear affecting both the enamel and dentine producing a flat and inclined surface. This inclined surface was probably responsible for the incrustation of a bone fragment during feeding. This foreign bone fragment is a piece of cortical bone identified under a binocular magnifier that allows observing the osseous pattern. This fragment was localized in the mesial P4 alveolus at the space left by the broken root during preparation (Fig. 4.6). It produced a compression and consequently lyses of the alveolar bone's labial border.

The female MACN 43 is a large and old adult (see Soibelzon, 2004, 2012). The left M2 was fractured in vivo at the labial margin of the talonid. On the right side, the P4 and M1 were fractured in vivo, $\mathrm{P} 4$ was completely lost except for the metacone root. In turn, the M1 shows a fracture on the labial border and on the distal border. Finally, the M2 protocone was also lost by a fracture and the enamel of the lingual margin of the talonid was lost by a superficial fracture. No pulp exposure was observed, the fracture only affected the dentine and enamel and attrition remodeled the dentine (see Fig. 4.1).

Some specimens exhibit chips or minor fractures on the $\mathrm{m} 2$ enamel: MMPH 018, MLP 97-II-2-1 (Fig. 4.7), MPV 614, MNHNP-PAM 179, MMMP1232, MPS 60. Several specimens show the same pathology in other teeth: NHM 32916 (m3), MLP 97-II-2-1 (m1) (Fig. 4.7), MACN 43 (left P4 and M1) (Fig. 4.1).

Finally, caries (type III) were first noticed in $A$. angustidens by Ferigolo and Berman (1993); we found other specimens with this pathology. MACN 12529 shows caries on the occlusal side at the paracone level of the left $\mathrm{P} 4$, and caries are observed at the talonid of the left M2 (see Fig. 4.8). On the right M2 of MLP-82-X-22-1, there are caries over the paracone on the labial side (Fig. 4.2, 4.6). On the left P4 of MACN 43 could be observed occlusal caries at the paracone level that would have produced a periapical infection. On the $\mathrm{m} 1$ of MLP 97-II-2-1 there are caries on the lingual side at the trigonid-talonid boundary. On the $\mathrm{m} 2$ of MPV614 , could be observed caries at the protoconid base on the labial side. On the $\mathrm{m} 2$ of MNHNP-PAM 179 there are caries at the hypoconid labial side. Finally, specimen MACN 2547 shows caries over the labial side of paraconid and metaconid of M2 and on the mesial side of $\mathrm{P} 4$ paraconid.

Morphology. - The giant SFB dental morphology has a mix of carnivore-omnivore characteristics: P4 with large, tall, and laterally compressed paracone and metacone forming a sharp blade; $\mathrm{m} 1$ with tall paracone and protocone, but wide and massive trigonid and well developed talonid. The molars show many accessory cusps, large occlusal surfaces in relation to skull size, and a cranial architecture mechanically suited to exert large bite forces. But probably the most astonishing characteristic of $A$. angustidens is the huge size of the cheek teeth relative to the skull size; $\mathrm{P} 4-\mathrm{M} 2$ and $\mathrm{p} 4-\mathrm{m} 3$ are really massive (ratio SL/P4M2 $=4$ and ratio SL/M1W=11.7) even compared with Arctodus simus (Cope, 1879) (the North American giant SFB; ratio SL/P4M2 $=5$ and ratio $\mathrm{SL} / \mathrm{M} 1 \mathrm{~W}=16.8$ ); and Ursus spelaeus Rosenmüller, 1794 (the cave bear; ratio $\mathrm{SL} / \mathrm{P} 4 \mathrm{M} 2=5$ and ratio $\mathrm{SL} / \mathrm{M} 1 \mathrm{~W}=26.4$ ). In this sense, Ailuropoda melanoleuca David 1869 also shows huge cheek teeth relative to skull size (the giant panda; ratio $\mathrm{SL} / \mathrm{P} 4 \mathrm{M} 2=4.8$ and ratio $\mathrm{SL} / \mathrm{M} 1 \mathrm{~W}=9.3$ ); and a similar $\mathrm{M} 1-\mathrm{M} 2$ and $\mathrm{m}-\mathrm{m} 3$ morphology that $A$. angustidens (the most important difference is that in the former the main cusps are laterally compressed and tapered and the crowns are very low while in the latter the main cusps are conical and blunt and the crown relatively high), but the P2-P4 and $\mathrm{p} 2-\mathrm{m} 1$ teeth are very different than those of $A$. angustidens and present characters that represent clear adaptation to cut bamboo leaves and thin steams. Noticeably, not one of the tens of specimens of giant panda studied presented enamel chips or broken crowns (LHS personal observ.).

The mandibular condyle is located slightly above the lower teeth row (using as reference a line uniting the crowns of $\mathrm{m} 1$ and $\mathrm{m} 2$ ), in an intermediate position between the conditions observed in carnivores hypercarnivores (e.g., Puma, Felidae) in which the condyle is at the same height or slightly below the teeth row and hypocarnivores (e.g., Procyon, Procyonidae) in which the condyle 


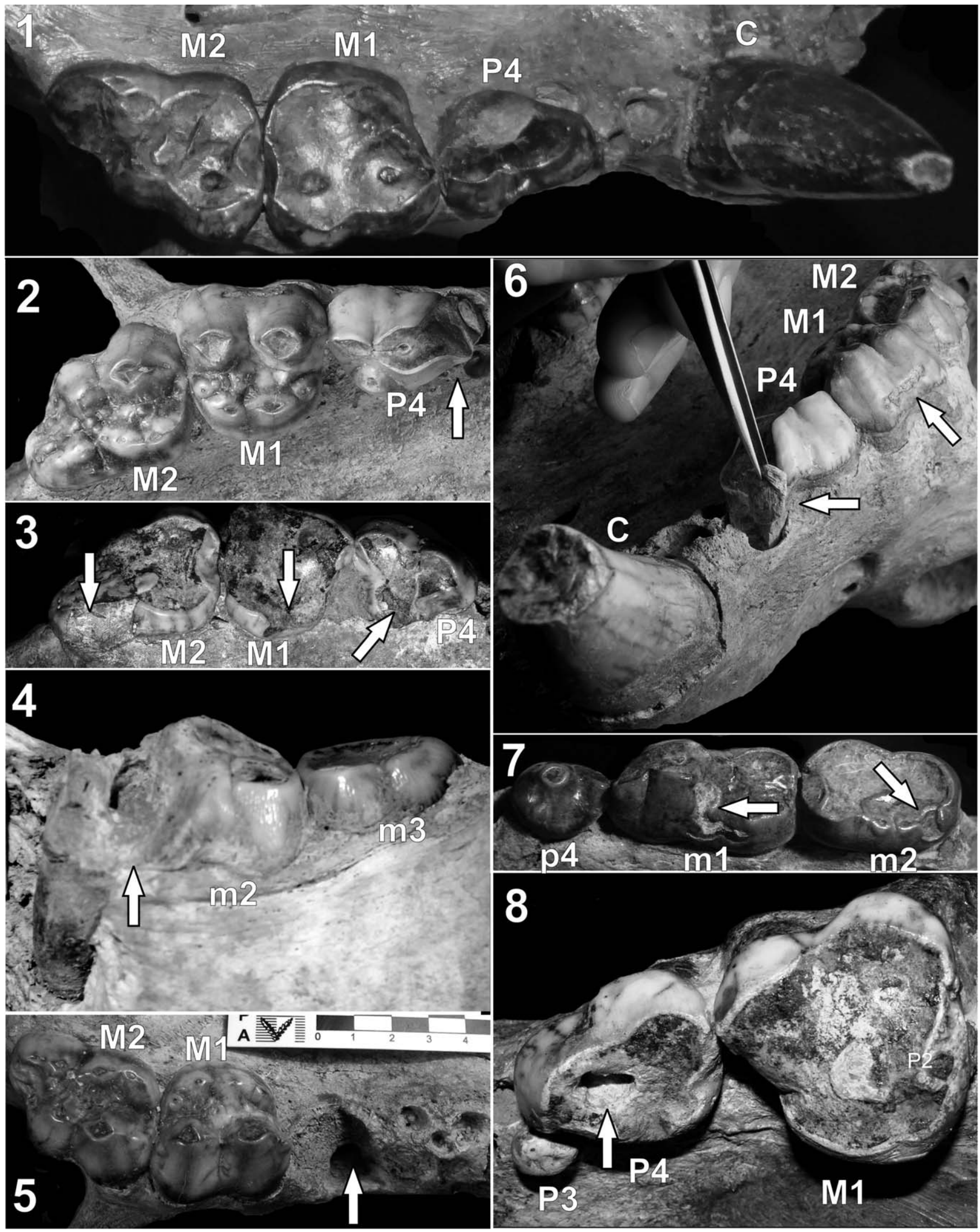

FIgURE 4-Paleopathologies observed on teeth of Arctotherium angustidens. 1, occlusal view of the left upper teeth row of MACN 43;2, occlusal view of the right upper teeth row of MLP 82-X-22-1; 3, occlusal view of the right upper teeth row of MACN 12529; 4, labial view of left m2-m3 of MMP 3980; 5, occlusal view of left upper teeth row of MLP 82-X-22-1; 6, antero-lateral view of the palate and right teeth row of MLP 82-X-22-1 showing the extraction of a foreign bone fragment during preparation; 7, occluso-lingual view of lower right teeth row of MLP 97-II-2-1; 8, occlusal view of upper left teeth row of MACN 12529. White bars indicate a reconstructed area. Arrows indicates pathologies mentioned in the text. 
TABLE 3-Bite force (BF) and Bite force quotient (BFQ). Error range of BFQ between parentheses.

\begin{tabular}{lccc}
\hline \hline & \multicolumn{3}{c}{ Specimen } \\
\cline { 2 - 4 } & MLP 82-X-22-1 & MACN 12529 & MACN 48 \\
\hline Bite force (N)-Upper canine & $1,090.77$ & $1,194.44$ & $1,055.50$ \\
Bite force (N)-P4 & $1,571.64$ & $1,542.89$ & $1,371.96$ \\
Bite force (N)-M2 & $2,299.33$ & $2,240.26$ & $1,846.80$ \\
Bite force quotient-Upper & 38.94 & 44.28 & 38.91 \\
$\quad$ canine & $(49.79-30.46)$ & $(56.52-34.69)$ & $(49.68-30.48)$ \\
Bite force quotient-M2 & 56.27 & 61.25 & 46.64 \\
& $(72.10-43.92)$ & $(78.36-47.87)$ & $(59.68-36.45)$ \\
\hline
\end{tabular}

is clearly above the teeth row. Compared with living ursids, the position is similar to Ursus americanus Pallas, 1780 while in $U$. maritimus Phipps, 1774 the position of the condyle is lower, and in U. spelaeus and Ailuropoda melanoleuca it is higher.

Biomechanics.- The results of the BF and BFQ estimations are outlined in Table 3; the MFP of the specimens studied are shown in Figure 5. Although BFQ mean value is very low, the absolute mean value of BF obtained at the canine, P4 and M2 shows a great strength in those positions. Compared to living ursids (Table 4), the estimated $\mathrm{BF}$ is only smaller than in Ailuropoda melanoleuca $\left(m=117.5 \mathrm{~kg} ; \quad \mathrm{BF}_{\mathrm{canin}}=1,298.9 \mathrm{~N}\right.$; $\mathrm{BF}_{\text {carnassial }}=1,815.9 \mathrm{~N} ; \mathrm{BFQ}_{\text {canine }}=151.4 \mathrm{~N} ; \mathrm{BFQ}_{\text {carnassial }}=141.8$ $\mathrm{N}$, being $m$ body mass), Ursus arctos $(m=251.2 \mathrm{~kg}$; $\mathrm{BF}_{\text {canine }}=1,409.7 \mathrm{~N} ; \mathrm{BF}_{\text {carnassial }}=1,894.9 \mathrm{~N} ; \mathrm{BFQ}_{\text {canine }}=99.3 \mathrm{~N}$; $\left.\mathrm{BFQ}_{\text {carnassial }}=90.3 \mathrm{~N}\right)$ and Ursus maritimus $(m=354.8 \mathrm{~kg}$; $\mathrm{BF}_{\text {canine }}=1,646.7 \mathrm{~N} ; \mathrm{BF}_{\text {carnassial }}=2,349.6 \mathrm{~N} ; \mathrm{BFQ}_{\text {canine }}=92.3 \mathrm{~N}$; $\mathrm{BFQ}_{\text {carnassial }}=89.4 \mathrm{~N}$ ).

The MFP suggests that bite force is very large at the canine. The relative force $(\mathrm{Zx} / \mathrm{Zy})$ observed at the canine is very close to 1 , which reflects an adaptation to withstand dorso-ventral and latero-medial loads (equally deep and wide mandibular corpus). The MFP also show a peak of force at the $\mathrm{p} 4$ and $\mathrm{m} 2$, being the relative force in those positions greater than 1 , describing a mandible adapted to resist dorsoventral loads (deeper than wide mandibular corpus).
Isotopic analysis.-For the seven enamel samples of different herbivorous species and Arctotherium angustidens from Toscas del Rio de la Plata site, the carbonate content range from 2.9-5.8 percent (Table 5), well within the range of such values in fresh enamel and therefore indicate a good preservation (Ecker et al., 2013). The $\delta^{13} \mathrm{C}$ values range from -11.2 to $-8.4 \%$ in herbivores, while the $\delta^{13} \mathrm{C}$ values of both $A$. angustidens samples are nearly identical $(-12.6$ and $-12.7 \%)$. The difference between the $\delta^{13} \mathrm{C}$ values of $A$. angustidens and coeval herbivores range from -4.2 to $-4.4 \%$, with an average of $-2.7 \% \pm 1.01 \%$ (Table 5).

The difference between the carbon isotopic results of $A$. angustidens and coeval herbivores were compared to these exhibited between Pleistocene brown bear (Ursus arctos) and cave bears (Ursus spelaeues) in European sites and the coeval carnivores and herbivores (Bocherens et al., 1995b; Garcia Garcia et al., 2009; Feranec et al., 2010; Ecker et al., 2013). Brown bears seem to have been mainly carnivores during the Pleistocene in Europe (Bocherens et al., 2011) while cave bears were essentially herbivores (Bocherens et al., 1994, 2006, 2011). The results clearly show that the difference between $\delta^{13} \mathrm{C}$ values of $A$. angustidens and herbivores is lower than for European Pleistocene carnivores but slightly higher than for European Pleistocene carnivorous brown bears, and clearly higher than for herbivorous cave bears.

\section{DISCUSSION}

Most bears can be considered opportunistic omnivores, consuming vegetation, fruits, arthropods, small and large vertebrates, and carrion according to availability (Sacco and Van Valkenburgh, 2004). The giant SFB (Arctotherium angustidens) has been considered a frugivore (Gervais, 1873), an omnivore (Ameghino, 1916a, 1916b), an omnivore with bone crushing capabilities (Soibelzon, 2012), and recently an omnivore whose diet included a considerable amount of meat (see Figueirido and Soibelzon, 2009). The only living relative of the giant SFB, the spectacled bear (Tremarctos ornatus), is an omnivore-hypocarnivore (see Peyton, 1980) since its diet

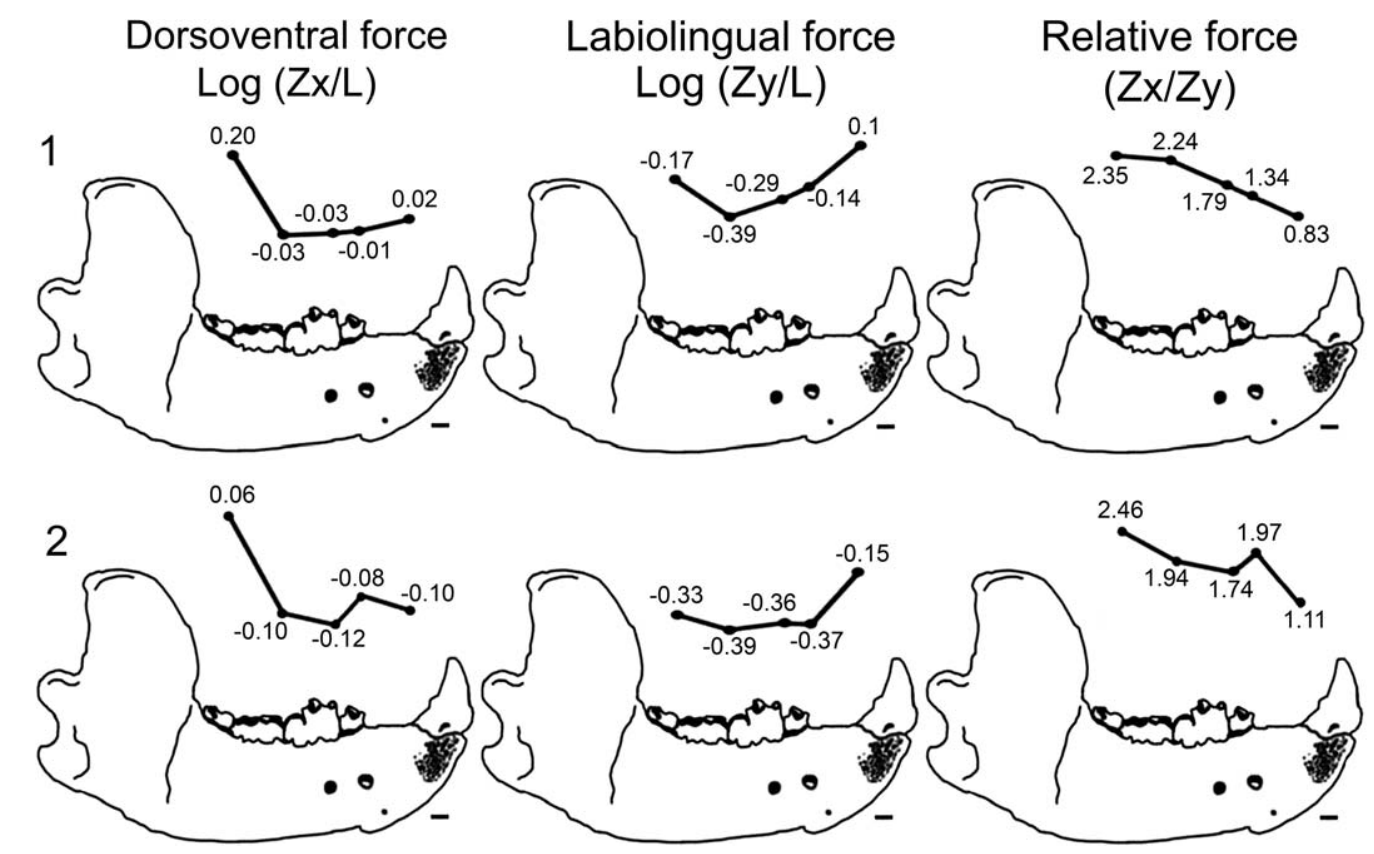

FiguRE 5-Mandibular force profiles of Arctotherium angustidens. Line 1: BMNH 32916 and line 2: MMPH 018. The values are presented in the following sequence from left to right, in agreement with the interdental gaps: $\mathrm{m} 3-\mathrm{m} 2, \mathrm{~m} 2-\mathrm{m} 1, \mathrm{~m} 1-\mathrm{p} 4, \mathrm{p} 4-\mathrm{p} 3$ and a point distal to canine. Scale bars $=1 \mathrm{~cm}$. 
TABLE 4-Extant bear species and Arctotherium angustidens BF and BFQ mean values compared.

\begin{tabular}{|c|c|c|c|c|c|}
\hline Species & Body mass (kg) & $\mathrm{BF}_{\text {canine }}(\mathrm{N})$ & $\mathrm{BFQ}_{\text {canine }}$ & $\mathrm{BF}_{\text {carnassial }}(\mathrm{N})$ & $\overline{\mathrm{BFQ}_{\text {carnassial }}}$ \\
\hline Arctotherium angustidens & $677^{1}$ & $1,113.57^{1}$ & $40.56^{1}$ & $2,128.8^{1}$ & $54.72^{1}$ \\
\hline Ailuropoda melanoleuca ${ }^{*}$ & 117.5 & $1,298.9$ & 151.4 & $1,815.9$ & 141.8 \\
\hline Tremarctos ornatus* & 100.0 & 795.1 & 103.1 & 946.6 & 82.1 \\
\hline Ursus americanus* & 140.0 & 744.3 & 77.2 & $1,003.6$ & 69.9 \\
\hline Ursus malayanus ${ }^{*}$ & $\begin{array}{r}231.2 \\
60.1\end{array}$ & $\begin{array}{r}1,409.1 \\
883.2\end{array}$ & 160.5 & $1,189.6$ & 143.6 \\
\hline Ursus maritimus ${ }^{*}$ & 354.8 & $1,646.7$ & 92.3 & $2,349.6$ & 89.4 \\
\hline Ursus thibetanus ${ }^{*}$ & 125.9 & 858.3 & 95.6 & $1,135.7$ & 84.8 \\
\hline Ursus ursinus* ${ }^{*}$ & 120.2 & 522.1 & 59.9 & 712 & 54.7 \\
\hline
\end{tabular}

* Values from Christiansen and Wroe (2007).

${ }^{1}$ Mean value from three specimens studied.

consists of 75 percent of vegetation (e.g., 22 species of Bromeliacea, 11 species of Cactacea, and fruits of 31 species of trees) but does not disregard fresh meat or carcass if the opportunity presented. Among animals eaten are small deer (Mazama Rafinesque 1817), rodents and insects (Nowak, 1999), sheep, cow, and tapir (Garshelis, 2009; Castellanos and Laguna, 2012; Laguna and Castellanos, 2012).

Davis (1964) has shown that some anatomical features (e.g., elevated cranio-mandibular articulation, reduced angular process) are associated with herbivory in modern bears (e.g., Tremarctos ornatus and Ailuropoda melanoleuca). Kurtén (1966) associated similar features with herbivory in two fossil bears: Tremarctos floridanus and Ursus spelaeus. In turn, Voorhies and Corner (1982) linked the absence of these characters in Arctodus with predatory habits. On this respect $A$. angustidens matches better with the condition observed in Ursus arctos than with that of any other living bear.

The values of BF obtained from the dry skull approach at the canine, P4 and M2 (see Table 3), are higher than those estimated for large extant and extinct predators such as Crocuta crocuta, Panthera onca, Smilodon fatalis, and Canis dirus. It has been observed in the extant species and suggested for the extinct species that they were able to kill large mammals (Therrien $2005 \mathrm{a}, \mathrm{b}$, and references therein). It can be claimed that a high value of $\mathrm{BF}$ is consistent with the ability to kill large preys. However, the picture is not clear if we make a comparison with other living ursids such as Ailuropoda melanoleuca, its high BF value seems to be an adaptation for feeding on rough plant matter not to kill large prey (Christiansen, 2007).

The MFP shows a peak of force at the p4 suggesting that it was probably used to break bones (or other hard items), but large bite forces are estimated by the MFP in all the cheek teeth (see Table 2 and Fig. 5). The variation of the relation between $\mathrm{Zx} / \mathrm{Zy}$ along the mandible is very similar to Ailuropoda melanoleuca, Tremarctos ornatus, and Ursus americanus (Christiansen, 2007, Del Moral et al., 2009). However, in other carnivores $\mathrm{Zx} / \mathrm{Zy}$ values close to 1 at canines are generally associated with an adaptation against stresses induced while biting prey, either due to struggling motions or to other torsional stresses in the mandibular symphysis produced by cracking hard objects (e.g., bone) with the posterior teeth (Therrien, 2005a). From the biomechanical standpoint, the general emerging picture does not contradict the hypothesis that $A$. angustidens was able to process hard food items like bones. This is also supported by some new evidence, as type II lesions found in the teeth of $A$. angustidens (see above). Our results suggest that the mandible seems to be stronger than needed for static bite. Moreover, the differences among the bite force suggested by BFQ and MFP methods is larger than in any living bear. A very low value of BFQ and a very powerful bite at the position of the canines (based on MFP values) have already been observed in Thylacosmilus atrox (Therrien, 2005b; Wroe et al., 2005) and have been interpreted to indicate a special killing technique very different from that of extant species.

One of the specimens of Arctotherium angustidens (MLP 82$\mathrm{X}-22-1)$ has the masseter cross section area larger than the temporal cross section area (see Table 1) in contrast to the condition observed in living bears (Davis, 1964; Elbroch, 2006; Christiansen, 2007). It was generally observed that active predators (for the particular case of bears see Christiansen, 2007) have temporal muscles more powerful than masseter muscles. Although we need more specimens to confirm this condition in $A$. angustidens and rule out some ontogenetic or sexual dimorphic causes (MLP-82-X-22-1 specimen is a young adult female), it could be related with the need of large backwards forces in the mandible in order to resist the force of the struggling prey (Maynard Smith and Savage, 1959).

This condition could be an argument for a low prevalence of living large prey on the diet of the giant SFB and for high scavenging habits. But, at this point it is very interesting to describe the hunting method used by Tremarctos ornatus (the only living representative of the group) for large prey (e.g., tapirs, cow, pig, and horses Castellanos and Laguna, 2012; Laguna and Castellanos, 2012; Laguna, 2011a, 2011b): the bear pursues or surprises the prey and when it finds the appropriate occasion it mounts over the back of the prey immobilizing it

TABLE 5-13C values of tooth enamel of Arctotherium angustidens and coeval herbivores in "Toscas del Rio de la Plata" site. The column $\delta 13 \mathrm{C}$ (A-herb) represents the difference between the $\delta 13 \mathrm{C}$ values of Arctotherium angustidens and that of each analyzed herbivore.

\begin{tabular}{|c|c|c|c|c|c|c|c|}
\hline Lab \# & Site & Age & Taxon & Sample \# & $\begin{array}{c}\mathrm{CO}_{3} \text {-content } \\
\text { (weight } \% \text { ) }\end{array}$ & $\begin{array}{c}\delta^{13} \mathrm{C} \\
\left(\%{ }_{0} \mathrm{PDB}\right)\end{array}$ & $\Delta \delta^{13} \mathrm{C}$ (A-herb) \\
\hline ARG-2 & Toscas del Rio de La Plata & Ensenadan (early Pleistocene) & Mesotherium & MACN 11825 & 5.83 & -9.9 & -2.7 \\
\hline ARG-3 & Toscas del Rio de La Plata & Ensenadan (early Pleistocene) & Hemiauchenia & MACN 2167 & 3.02 & -8.4 & -4.2 \\
\hline ARG-4 & Toscas del Rio de La Plata & Ensenadan (early Pleistocene) & Hemiauchenia & MACN 2169 & 2.91 & -9.9 & -2.8 \\
\hline ARG-5 & Toscas del Rio de La Plata & Ensenadan (early Pleistocene) & Hippidion & MACN 1876 & 3.73 & -11.2 & -1.4 \\
\hline ARG-6 & Toscas del Rio de La Plata & Ensenadan (early Pleistocene) & Hippidion & MACN 2151 & 3.48 & -10.2 & -2.4 \\
\hline ARG-7 & Toscas del Rio de La Plata & Ensenadan (early Pleistocene) & A. angustidens & MACN 2011 & 5.39 & -12.7 & \\
\hline \multirow[t]{2}{*}{ ARG-8 } & Toscas del Rio de La Plata & Ensenadan (early Pleistocene) & A. angustidens & MACN 2158 & 5.36 & -12.6 & \\
\hline & & & & & & $\begin{array}{l}\text { av } \\
\text { sd }\end{array}$ & $\begin{array}{l}-2.7 \\
1.01\end{array}$ \\
\hline
\end{tabular}


with its body mass and paws with powerful claws (Galasso, 2002; Castellanos, 2006; Goldstein et al., 2006; Laguna, 2011a, 2011b; Castellanos and Laguna, 2012; Laguna and Castellanos, 2012; Castellanos and Laguna, personal commun. to LHS, 2012). Then, the bear starts to consume the living prey from its back causing the death by shock and stress (Castellanos and Laguna, personal commun., 2012). Alternatively, the bear pursues the prey into rough terrain, hillsides, or precipices, provoking its fall and/or death. After death, the prey is dragged to a safe place (usually a nest over a tree, or a forested area) where the bear consumes it until only the skeletal parts impossible to be chewed (e.g., skull and diaphysis of long bones) are left (Castellanos, 2011; Laguna, 2011a, 2011b; Castellanos and Laguna, personal commun., 2012). So it is plausible to hypothesize that giant short-faced bears could have used the same hunting strategy.

The extent of occlusal wear in the giant SFB teeth is exceptional in relation to that observed in modern bears and comparable to that of Cave bears (Ursus spelaeus): molar crowns were often completely flatted in old bears across the Pampean Region (Soibelzon, 2012). In old giant SFB bears, the $\mathrm{m} 1$ and $\mathrm{m} 2$ were usually extremely worn and the pulp cavities were fully exposed prior to death. Koby (1940, 1953), Baryshnikov (1997), Kurtén (1976), and Stiner et al. (1998) postulated that the damage observed on the Cave bears cheek teeth could be related with the consumption of rough plant materials such as hard-coated seeds, tubers, and other roots, berries, and foliage. Matson (1998) reached a similar conclusion about Cave bear feeding habits based on interspecific morphometric comparisons of modern and Pleistocene bear crania (i.e., a heavy emphasis on root grubbing). Rothschild and Martin (2003) demonstrated that the flat-topped wear in molars could be associated with animals that manipulate bones. So, heavy tooth wear observed in $A$. angustidens could be explained by consumption of dried meat and bone (carcasses) and/or a coarse and rough diet.

Studies of extant carnivorans showed that elevated tooth fracture frequencies characterize species that crack large bones regularly, such as hyenas and wolves (Binder et al., 2002). Van Valkenburgh (1988) found that some species of large carnivorans showed an increasing incidence of broken teeth with age and that among nine recent species of large carnivores the most frequent broken teeth are canines, followed by premolars, carnassials, and incisors. Van Valkenburgh (1988) linked this situation to predation over large prey because of accidental fracture during killing. Rothschild and Martin (2003) observed that scavengers also show tooth breakage (some specimens in both sides of the jaw) due to errors in handling bones, as it was observed in the giant SFB (see above).

Noticeably, only one specimen (MARC 10232 2/242) of the later Arctotherium species (A. bonariense, Bonaerian-Lujanian of Pampean Region) shows a broken teeth (m2), although extreme wear of the occlusal molar surface remains common in the Bonaerian and Lujanian species of South America.

Arctotherium angustidens from only one site have been studied so far using the carbon stable isotopic composition of tooth enamel, but these preliminary results are fully consistent with a diet including large proportions of meat, similar to the situation of European brown bears during the Pleistocene and in contrast with the herbivorous cave bears. This result suggests an omnivorous diet with a large proportion of meat in the diet of $A$. angustidens in the site "Toscas del Rio de la Plata". Similar studies of more material and more sites will allow us to evaluate the variability of these dietary habits in time and space but these preliminary results are consistent with those of the other approaches.

In sum, evidence from anatomy, biomechanics, pathology and stable isotopes favors the idea of animal matter consumption, probably from large vertebrates in addition to vegetable matter consumption: 1) the relatively high number of specimens with broken teeth in life; 2) the piece of bone incrusted in the maxillar of MLP 82-X-22-1; 3) extreme teeth wear; 4) development of caries; 5) the MFP shows a relative force very close to 1 at the canine and a peak of force at the canine, $\mathrm{p} 4$ and $\mathrm{m} 2$, suggesting that probably $A$. angustidens was able to break bones, while BF obtained with the Dry Skull approach also showed great strength in those positions; and 6) stable isotopic pattern similar to that of mostly carnivorous Pleistocene brown bears in Europe. This is in agreement with the results obtained by Figueirido and Soibelzon (2009) from geometric morphometrics study of the mandible and skull of Arctotherium species.

Most probably, active hunting (possibly using a similar modus operandi than that observed on the Andean bear) was not the unique strategy of the giant SFB for feeding, since the large size and great power of the giant SFB may have permitted fight for preys hunted by other Pleistocene carnivore such as Smilodon (Soibelzon, 2012). On the other hand, scavenging megaherbivore carcasses was probably another frequent way of feeding as it is well known for the Andean bear and other living bears like Ursus arctos and $U$. americanus.

The huge $A$. angustidens became extinct at the middle Pleistocene (Soibelzon et al., 2005; Soibelzon and Schubert, 2011) when other species of SFB start to be recorded; interestingly Figueirido and Soibelzon (2009) proposed that these later species become more and more omnivore through time, with the youngest and smallest species $(A$. wingei) inferred to be mostly herbivorous. It was hypothesized by Soibelzon and Schubert (2011) that the South American carnivore guild diversification during the Pleistocene (from the few precursory taxa that crossed the Panamanian Isthmus during the GABI) provoked the SFB to adjust their size and modify their diet in order to survive in the more competitive ecosystems of the late Pleistocene.

\section{ACKNOWLEDGMENTS}

We are grateful to PEDECIBA and ANII. To A. Castellanos and A. Laguna from Andean Bear Foundation (andeanbear.org) for valuable and useful information on Andean bear predation behavior. Thanks are due to B. Steinhilber, H. Taubald and C. Wissing for technical assistance in the stable isotope measurements and to the Editor and the two anonymous reviewers for greatly improving the original ms. We acknowledge the financial funding of the Deutsche Forschungsgemeinchaft (DFG grant \# BO 3487/4-1), the Argentinean ANPCyT (PICT 0804, PICT 2007-00428, PICT 2011-309) and CONICET (PIP 0436, PIP 1054).

\section{REFERENCES}

AlexAnder, R. Mc N. 1981. Factors of safety in the structure of animals. Science Progress, 67:109-130.

Ameghino, C. 1916a. La fórmula dentaria del género Arctotherium. Physis, 2: 285-286.

Ameghino, C. 1916b. Sobre la dentadura superior de Arctotherium en edad juvenil. Physis, 2:435-437.

Ameghino, F. 1885. Nuevos restos de mamíferos fósiles oligocenos, recogidos por el profesor Pedro Scalabrini y pertenecientes al Museo provincial de la ciudad de Paraná. Boletín de la Academia de Ciencias de Córdoba, 8:3-207.

Ameghino, F. 1887. Enumeración sistemática de las especies de mamíferos fósiles coleccionados por Carlos Ameghino en los terrenos eocenos de Patagonia Austral y depositados en el Museo de La Plata. Boletín del Museo de La Plata, p. 1-26. 
Ameghino, F. 1891. Caracteres diagnósticos de cincuenta especies nuevas de mamíferos fósiles de la República Argentina. Revista Argentina de Historia Natural, 1:129-167.

Ameghino, F. 1902. Notas sobre algunos mamíferos fósiles nuevos o poco conocidos del valle de Tarija. Anales del Museo Nacional Buenos Aires, 3: 225-261.

BARyshnikov, G. 1997. Cave bears from the Paleolithic of the Greater Caucasus, p. 69-118. In J. J. Saunders, B. W. Styles and G. Baryshnikov (eds.), Quaternary Paleozoology in the Northern Hemisphere. Scientific papers of the Illinois State Museum, Springfield, Illinois.

Binder, W. J., E. N. Thompson, and B. Van Valkenburgh. 2002. Temporal variation in tooth fracture among Rancho La Brea Dire wolves. Journal of Vertebrate Paleontology, 22:423-428.

Blanco, R. E., W. W. Jones, and G. A. Grinspan. 2011. Fossil marsupial predators of South America (Marsupialia, Borhyaenoidea): bite mechanics and palaeobiological implications. Alcheringa, 35:377-387.

Bocherens, H. 2000. Preservation of isotopic signals $(13 \mathrm{C}, 15 \mathrm{~N})$ in Pleistocene mammals, p. 65-88. In M. A. Katzenberg and S. H. Ambrose (eds.), Biogeochemical Approaches to Paleodietary Analyses. Kluwer Academic/Plenum Publishers New York.

Bocherens, H., M. Fizet, and A. Mariotti. 1994. Diet, physiology and ecology of fossil mammals as inferred by stable carbon and nitrogen isotopes biogeochemistry: implications for Pleistocene bears. Palaeogeography, Palaeoclimatology, Palaeoecology, 107:213-225.

Bocherens, H., S. Emslie, D. Billiou, and A. Mariotti. 1995a. Stable isotopes (C13, N15) and paleodiet of giant short-faced bear (Arctodus simus). Comptes Rendus de l'Académie des sciences Paris, 320:779-784

Bocherens, H., M. L. Fogel, N. Tuross, And M. Zeder. 1995b. Trophic structure and climatic information from isotopic signatures in a Pleistocene cave fauna of Southern England. Journal of Archaeological Science, 22: 327-340.

Bocherens, H., P. L. Koch, A. Mariotti, D. Geraads, and J. J. Jaeger. 1996. Isotopic biogeochemistry $(13 \mathrm{C}, 18 \mathrm{O})$ of mammal enamel from African Pleistocene hominid sites: implications for the preservation of paleoclimatic isotopic signals. PALAIOS, 11:306-318

Bocherens, H., D. G. Drucker, D. Billiou, J.-M. Geneste, and J. van der Plicht. 2006. Bears and humans in Chauvet Cave (Vallon-Pont-d'Arc, Ardèche, France): insights from stable isotops and radiocarbon dating of bone collogen. Journal of Human Evolution, 50:370-376.

Bocherens, H., O. Sandrock, O. Kullmer, and F. Schrenk. 2011. Hominin palaeoecology in late Pliocene Malawi: insights from isotopes $(13 \mathrm{C}, 18 \mathrm{O})$ in mammal teeth. South African Journal of Science, 107:95-100.

Burmeister, H. 1879. Description physique de la République Argentine d' prés des observationes personelles et étrangéres. Traduit de l'allemand avec le concourse de E. Daireaux. Tome troisiéme: Animaux vertébrés. Premiére partie: Mammiféres vivants et éteints. Buenos Aires, 3(1):1-556, with atlas.

Castellanos, A. 2006. Cannibalism in Andean Bears? International Bear News, Quarterly Newsletters of the International Association for Bear Research and Management (IBA) and the IUCN/SSC Bear Specialis Group, 15(4):20.

Castellanos, A. 2011. Do Andean Bears attack Mountain Tapirs? International Bear News, 20:41-42.

Castellanos, A. X. And A. Laguna. 2012. Depredación a ganado vacuno y mamíferos silvestres por oso andino en el norte de ecuador.X Congreso Internacional de Manejo de Fauna Silvestre en la Amazonía y Latinoamérica. Salta, Abstracts (electronic version without pagination).

Christiansen, P. 2007. Evolutionary implications of bite mechanics and feeding ecology in bears. Journal of Zoology, 272:423-443.

Christiansen, P. And S. Wroe. 2007. Bite forces and evolutionary adaptations to feeding ecology in carnivores. Ecology, 88:347-358.

Cione, A., E. P. Tonni, And L.H. Soibelzon. 2009. Did humans cause mammal late Pleistocene-Holocene extinction in South America in a context of shrinking open areas?, p. 125-143. In G. Haynes (ed.), American Megafaunal Extinctions at the End of the Pleistocene, Springer Publishers, Vertebrate Paleobiology and Paleontology Series, U.S.A.

Clementz, M. T., K. Fox-Dobbs, P. V. Wheatly, P. L. Koch, and D. F. Doak. 2009. Revisiting old bones: coupled carbon isotope analysis of bioapatite and collagen as an ecological and palaeoecological tool. Geological Journal, 44:605-620.

Close, R. I. 1972. Dynamic properties of mammalian skeletal muscles. Physiological Reviews, 52:129-197.

Cope, E. D. 1879. The cave bear of California. American Naturalist, 13:791.

Cope, E. D. 1880. On the extinct cats of America. American Naturalist, 14: 833-858.

Cuvier, F. G. 1825. Tremarctos ornatus. In E. Geoffroy Saint-Hilaire and F. G. Cuvier (eds.), Histoire Naturelle des Mammiferes, vol. 3, p. 50

DAvid, A. 1869. Etrait d'une lettre du me̊me, dateé de la Principaute Thibetaine (independente) de Mou-pin, le 21 Mars 1869. Nouv Arch Museum Histoire Naturelle de Paris, Bulletin, 5:12-13.
DAvis, D. D. 1964. The giant panda. A morphological study of evolutionary mechanism. Fieldiana-Zool., Mem., Chicago Museum of Natural History, 3: $1-399$.

Del Moral Sachetti, F. J., R. Zenteno Cardenas, and F. I. Lameda Camacaro. 2009. Análisis biostático de las tensiones actuantes en el dentario del oso andino (Tremarctos ornatus) durante la mordedura. Acta Zool Mexicana 25:551-567.

Ecker, M. 2011. Stable Isotope Analyses on the Fauna from Payre (Ardèche, France). MS Thesis, University of Tuebingen.

Ecker, M., H. Bocherens, M. A. Julien, F. Rivals, J. P. Raynal, and M. H. Moncel. 2013. Middle Pleistocene ecology and Neanderthal subsistence: insights from stable isotope analyses in Payre (Ardèche, France). Journal of Human Evolution, 65:363-373.

Elbroch, M. 2006. Animal Skulls: A Guide to North American Species. Stackpole Books, 740 p.

Feranec, R., N. García, J. C. Díez, and J. L. Arsuaga. 2010. Understanding the ecology of mammalian carnivorans and herbivores from Valdegoba cave (Burgos, northern Spain) through stable isotope analysis. Palaeogeography, Palaeoclimatology, Palaeoecology, 297:263-272.

FERIGOLO, J. 1992. Non-human vertebrate paleopathology of some Brazilian Pleistocene mammals, p. 213-234. In A. J. G. Araujo and L. F. Ferreira (eds.), Paleopatologia and Paleoepidemiologia-Estudos Multidisciplinares. Rio de Janeiro, Panorama/Escola Nacional de Saude Publica.

Ferigolo, J. and W. D. Berman. 1993. Dental paleopatology and Paleodiet of Arctotherium bonariensis (Mammalia, Carnivora, Ursidae) from the Ensenadan (lower to middle Pleistocene), Buenos Aires Province, Argentina. Congresso Brasileiro de Paleontologia, Sao Leopoldo, Abstracts, 13.

Figueirido, B. AND L. H. SoIBElzon. 2009. Inferring paleoecology in extinct tremarctine bears (Carnivora, Ursidae) via geometric morphometrics. Lethaia, 43:209-222.

Galasso, L. 2002. The spectacled bear's impact on livestock and crops and use of remnant forest fruit trees in an human altered landscape in Ecuador. MS Thesis, University of Wisconsin, Madison.

Garcia Garcia, N. R., S. Feranec, J. L. Arsuaga, J. M. Bermúdez de Castro, AND E. CARBonell. 2009. Isotopic analysis of the ecology of herbivores and carnivores from the middle Pleistocene deposits of the Sierra De Atapuerca, northern Spain. Journal of Archaeological Science, 36:1,142-1,151.

Garshelis, D. L. 2009. Family Ursidae (Bears), p. 448-497. In D. E. Wilson and R. A. Mittermeier (eds.), Handbook of the Mammals of the World, Vol. 1, Carnivores. Barcelona, Lynx Editions.

Gervais, P. 1848-1852. Zoologie et Paleontologie francaises (animaux vertébrés) ou nouvelles recherches sur les animaux vivantes et fossiles de la France, A. Bertrand, Paris, 271 p.

Gervais, P. 1873. Mémoire sur plusieurs espéces de mammiféres fossiles propres á l' Amerique méridionale. Mémoires de la Société géologique de France, (2) IX (5):1-44.

Gervais, H. And F. Ameghino. 1880. Los Mamíferos Fósiles de la América del Sur. Salbi e Igon. París and Buenos Aires, 225 p.

Goldstein, I., S. Paisley, R. Wallace, J. Jorgenson, and A. Castellanos. 2006. Andean bear-livestock conflicts: a review. Ursus, 17:8-15.

Koвy, F. E. 1940. Les usures séniles des canines d'Ursus spelaeus et al préhistoire. Verhandlungen der naturforschenden Gesellschaft in Basel, 51: 76-95.

Koby, F. E. 1953. Modifications que les ours des cavernes ont fait subir à leur habitat. Premier Congrès International de Spéléologie, 4:15-27.

KuRTÉn, B. 1966. Pleistocene bears of North America: 1 Genus Tremarctos, spectacled bears. Acta Zoologica Fennica, 115:1-120.

KURTÉn, B. 1976. The cave bear story. Columbia University, New York, New York, U.S.A., 163 p.

Laguna, A. A. 2011a. Metodología para el estudio de depredación a ganado por el oso andino (tremarctos ornatus) en los andes nororientales del ecuador. I Congreso Ecuatoriano de Mastozoología, Abstracts, 1:197.

Laguna, A. A. 2011b. Resultados preliminares del conflicto hombre-oso en el norte de Ecuador. Actas del I Congreso Ecuatoriano de Mastozoología, p. 198

Laguna, A. A. And A. X. Castellanos. 2012. Uso de trampas cámara para la identificación de osos andinos (Tremarctos ornatus) residentes y predadores de ganado en los Andes nororientales del Ecuador. X Congreso Internacional de Manejo de Fauna Silvestre en la Amazonía y Latinoamérica. Salta, Abstracts (electronic version without pagination).

LEIDY, J. 1858. Notice of remains of extinct Vertebrata, from the Valley of the Niobrara River, collected during the exploring expedition of 1857, in Nebraska, under the command of Lieut. G. K. Warren, U. S. Top. Eng., by Dr. F. V. Hayden, geologist of the Expedition. Proceedings of the Academy of Natural Sciences, 1858: 20-29.

Lund, P. W. 1842. Blik paa Brasiliens Dyreverden för sidste jordomvaeltning. Fjerde Afhandling: Fortsaettelse af Pattedyrene. Lagoa Santa d. 30 Januar 1841. Copenhague. -K. Danske videnskabernes Selskabs naturvidenskapelige og mathematiske Afhandlinger, 9:137-208. 
Marshall, L. G., S. D. Webb, J. J. Sepkoski, and D. M. Raup. 1982. Mammalian evolution and the Great American Interchange. Science, 215: $1,351-1,357$

Martin, L. D., J. P. Babiarz, V. L. Naples, and J. Hearst. 2000. Three ways to be a saber-toothed cat. Naturwissenschaften, 87:41-44

Matson, D. J. 1998. Diet and morphology of extant and recently extinct northern bears. Ursus, 10:479-496.

Maynard Smith, J. And R. J. G. Savage. 1959. The mechanics of mammalian jaws. School Science Review, 40:289-301.

Mones, A. And A. Rinderknecht. 2004. The first South American Homotheriini (Mammalia: Carnivora: Felidae). Comunicaciones Paleontológicas del Museo Nacional de Historia Natural y Antropología, 35:201212.

NowaK, R. M. 1999. Walker's Mammals of the World. The Johns Hopkins University Press, Sixth Edition, U.S.A., 1,362 p.

Owen, R. 1869. On fossil teeth of equines from Central and South America refereable to Equus conversidens, Equus tau, and Equus arcidens. Proceedings of the Royal Society of London, 17:267-268.

Pallas, P. S. 1780. Spicilegia Zoologica, quibus novae imprimis et obcurae animalium species iconibus. Berolini, G. A. Lange, 1774-1780. Fasicle 14, p. 5.

Peyton, B. 1980. Ecology, distribution and food habits of spectacled bears Tremarctos ornatus, in Peru. Journal of Mammalogist, 61:639-652.

PhIPPS, C. J. 1774. A voyage towards the North Pole. Journal of Nourse, London, $253 \mathrm{p}$

Prevosti, F. And L. H. Solbelzon. 2012. Evolution of the South American carnivores (Mammalia, Carnivora): a paleontological perspective, p. 102122. In B. D. Patterson and L. P. Costa (eds.), Bones, Clones, and Biomes: An 80-Million Year History of Modern Neotropical Mammals. University of Chicago Press.

Pushinan, D., H. Bocherens, Y. Chaimanee, and J. J. Jaeger. 2010. First dietary and paleoenvironmental reconstructions from the late Middle Pleistocene Snake cave in northeastern Thailand using stable carbon isotopes. Naturwissenschaften, 97:299-309.

RafinESQue, C. S. 1817. Museum of Natural Sciences. The American Monthly Magazine and Critical Review, 1:431-442.

Riggs, E. S. 1933. Descriptions of seven new genera of North America Quadrupeds. American Monthly Magazine, 2:44 46.

Rincón, A. D., F. J. Prevosti, and G. E. Parras. 2011. New saber-toothed cat records (Felidae-Machairodontinae) for the Pleistocene of Venezuela, and the Great American Biotic Interchange. Journal of Vertebrate Paleontology, 31:468-478.

Rodrigues S., C. Bernardes, L. H. Soibelzon, and L. Avilla. 2012. Os carnívoros (Carnivora: Mammalia) fósseis registrados nas cavernas do sudeste do Estado do Tocantins: taxonomia, aspectos climáticos e ambientais no Pleistoceno Superior do Brasil. $6^{\circ}$ Congreso Brasilero de Mastozoología, Corumbá, Abstracts (electronic version without pagination).

RosenMüller, J. C. 1794. Quaedam de ossibus fossilibus animalis cuiusdam, historiam eius et cognitionem accuratiorem illustrantia, dissertatio, quam d ad disputandum proposuit Ioannes Christ. Rosenmüller Heßberga-Francus, LL.AA.M. in Theatro anatomico Lipsiensi Prosector assumto socio Io. Chr. Aug. Heinroth Lips. Med. Stud. Cum tabula aenea. 34 p., 1 copperpl.; Leipzig.

RothschiLd, B. M. And L. D. Martin. 2003. Frequency of pathology in a large natural sample from Natural Trap Cave with special remarks on erosive disease in the Pleistocene. Rheumatismo, 55:58-65.

Sacco, T. and B. Van Valkenburgh. 2004. Ecomorphological indicators of feeding behaviour in the bears (Carnivora: Ursidae). Journal of Zoology, 263:41-54

SERres, M. 1867. De 1'osteographie du "Mesotherium" et des affinités zoologiques. Comptes Rendus de l'Academie des Sciences, 65:841-848.

Smith, J. B. AND P. Dodson. (2003). A proposal for a standard terminology of anatomical notation and orientation in fossil vertebrate dentitions. Journal of Vertebrate Paleontology, 23:1-12.

Soibelzon, L. H. 2002. Los Ursidae (Carnivora, Fissipedia) fósiles de la República Argentina. Aspectos sistemáticos y paleoecológicos. Unpublished Ph.D. Thesis, Universidad Nacional de La Plata.
SolBelzon, L. H. 2004. Revisión sistemática de los Tremarctinae (Carnivora, Ursidae) fósiles de América del Sur. Revista del Museo Argentino de Ciencias Naturales, 6:107-133.

SolBelzon, L. H. 2012. Los Ursidae, Carnivora Fissipedia, fósiles de la República Argentina: aspectos sistemáticos y paleoecológicos. First edition, La Plata: Universidad Nacional de La Plata, 239 p.

Solbelzon, L. H. AND F. PRevosti. 2007. Los carnívoros (Carnivora mammalia) terrestres del Cuaternario de América del Sur, p. 49-68. In G. X. Pons and D. Vicens (eds.), Geomorphologia Litoral i Quaternari. Homenatge a D. Joan Cuerda Barceló. Monografies de la Societat d'Història Natural de les Balears. Palma de Mallorca.

Soibelzon, L. H. And F. Prevosti. 2012. Fossils of South American Land Carnivores (Carnivora, Mammalia), p. 509-530. In M. Ruiz and J. Shostell (eds.), Molecular Population Genetics, Evolutionary Biology and Biological Conservation of Neotropical Carnivores. Nova Science Publisher, New York.

Soibelzon, L. H. AND A. Rincón. 2007. The fossil record of the short-faced bears (Ursidae, Tremarctinae) from Venezuela. Systematic, biogeographic and paleoecological implications. Neues Jahrbuch für Geologie und Paläontologie, 245:287-298.

Solbelzon, L. H. AND B. W. Schubert. 2011. The largest known bear, Arctotherium angustidens, from the early Pleistocene pampean region of Argentina: with a discussion of size and diet trends in bears. Journal of Paleontology, 85:69-75.

Soibelzon, L. H. and V. B. TARTARINI. 2009. Estimación de la masa corporal de las especies de osos fósiles y actuales (Ursidae, Tremarctinae) de América del Sur. Revista Museo Argentino de Ciencias Naturales "Bernardino Rivadavia", 11:243-254.

Soibelzon, L. H., L. M. Pomi, E. P. Tonni, S. Rodriguez, and A. Dondas. 2009. First Report of a short-faced bears' den (Arctotherium angustidens). Palaeobiological and palaeoecological implications. Alcheringa, 33:211222.

SolBelzon, L. H., E. P. Tonni, And M. Bond. 2005. The fossil record of South American short-faced bears (Ursidae, Tremarctinae). Journal of South American Earth Sciences, 20:105-113.

Stiner M. C., H. Achyuthagn, A. Rsebufk, C. Howells, K. Josephs, J. Jueld N. D. Pigatai, And J. Quade. 1998. Reconstructing cave bear paleoecology from skeletons: a cross-disciplinary study of middle Pleistocenebears from Yarimburgaz Cave, Turkey. Paleobiology, 24:74-98.

Therrien, F. 2005a. Mandibular force profiles of extant carnivorans and implication for the feeding behaviour of extinct predators. Journal of Zoology, London, 267:249-270.

THERRIEN, F. 2005b. Feeding behaviour and bite force of sabretoothed predators. Zoological Journal of the Linnean Society, 145:393-426.

Thomason, J. J. 1991. Cranial strength in relation to estimated biting forces in some mammals. Canadian Journal of Zoolology, 69:2,326-2,333.

Torres, T. 1988. Osos (Mammalia, Carnivora, Ursidae) del Pleistoceno de la Península Ibérica. Publicación especial del Boletín Geológico y Minero, Instituto Geológico y Minero de España XCIX, p. 1-316.

VALKENBURGH, B. VAN. 1988. Incidence of tooth breakage among large, predatory mammals. The American Naturalist, 131:291-301.

Valkenburgh, B. VAN And F. Hertel. 1993. Tough times at La Brea: tooth breakage in large carnivores of the late Pleistocene. Science, 261:456-459.

VoORHIES, M. R. AND R. G. CoRner. 1982, Ice age superpredators: University of Nebraska State Museum, Museum Notes, 70:1-4.

Woodburne, M., A. L. Cione, and E. P. Tonni. 2006. Central American Provincialism and the Great American Biotic Interchange, p. 73-101. In O Carranza-Castañeda and E. H. Lindsay (eds.), Advances in Late Tertiary Vertebrate Paleontology in Mexico and the Great American Biotic Interchange. Publicación Especial del Instituto de Geología y Centro de Geociencias de la Universidad Nacional Autónoma de México, Mexico.

Wroe, S., C. McHenry, and J. J. Thomason. 2005. Bite club: comparative biteforce in big biting mammals and the prediction of predatory behavior in fossil taxa. Proceedings of the Royal Society of London, Series B, 272:619 625 .

AcCepted 11 June 2014 